\title{
WAYS OF SEEING: THE POETICS AND POLITICS OF EXHIBITING ITALO-AUSTRALIAN CULTURES IN SYDNEY
}

\section{Ilaria Vanni}

\begin{abstract}
This article reflects on the theoretical nodes behind the organisation of the exhibition Italiani di Sydney, Museum of Sydney, 30 August- 7 December 2003. It argues that exhibitions are produced through situated knowledges and it analyses the particular situatedness of the curator. Notions of imagined communities, the poetics of the carnivalesque, the everyday, the importance of objects, cultural heritage in the making, heterogeneity and heteroglossia, gaps between official narratives and lived actualities, hybrid spaces, and hyperlinked narratives, are interwoven in the text with a review of the exhibition.
\end{abstract}

Self-identity is a bad visual system (Donna Haraway 1991: 192)

9 February 2003. A typically hot, washed out, summer day in Sydney. Five Dock Park looked parched and brown in the afternoon glare. Fig and palm trees offered no shadow. At one end of the park, stalls were selling mostaccioli and torroni calabresi marketed as gingerbread and nougat, 'hot and tasty' Dagwood Dog deep fried American sausages, 'crispy crunch' Belgian waffles, corni, soccer jumpers and inflatable aliens. A stage crowned by fairy lights in the colours of the Italian flag towered at the other end. There, people were assembling behind the banners of the confraternite (religious brotherhoods). It was the annual festa di San Bartolo Martire e Apostolo Protettore delle Isole Eolie, Sydney (Festival of Saint Bartholomew, Martyr and Apostle, Protector of the Aeolian Islands, Sydney). 
I was there to take photos and understand the context for an exhibition on Italians and Sydney that I had been commissioned to curate at the Museum of Sydney (MoS) on the site of First Government House, one of the Historic Houses Trust (HHT) of New South Wales properties, dedicated to offering the visitor 'a journey of discovery and wonder through Sydney 1788 and beyond' <http://www.hht.nsw.gov.au/ museums/museum_of_sydney/museum_of_sydney $>$.

I was born and raised in Tuscany where saints' festivals are a rare event. I approached the afternoon with a mixture of curiosity, excitement and carefulness, as this kind of event, I felt, lent itself to be orientalised into a multicultural picturesque.

The procession soon started. I followed it from within the park, taking photos of the different confraternite, of the committee, of the banners, as the procession strolled around the lower perimeter of the park. My position was a peculiar one: I was walking alone, observing the procession through the lens of my camera, which at the same time was quite literally a filter between me and the action. The camera was also one of the tools I had to read this particular event, a way of seeing that promised a demarcated, detailed, and organized vision. My camera was a tool that other people taking part in the event did not necessarily have. However, what I really wanted, for no particular reason as I am neither Catholic nor Aeolian, was to be in the middle of the procession, to encounter the people and experience it. I waited until a group of comari (women) came by, joined them and recited what I remembered of the Ave Maria learnt in primary school with much gusto, amidst the reprimands of the Italian priest who, rather than leading, was herding the procession from the end with the help of a loud-speaker: comari, questo non e' il posto per il pettegolezzo, smettete di parlare e pregate... (Ladies, this is no place to gossip, stop talking and pray). I realized that knowing the Ave Maria allowed me to be accepted by the comari and I went back up into the park to take better pictures of them. In this way, I followed the whole procession: watching and taking a few pictures up in the park while reciting the 
Ave Maria and more down on the pavement saying my prayers with the comari (Vanni, 2003: 1). ${ }^{1}$

\section{Local knowledge}

Donna Haraway (1991), tackling the issue of what a feminist objectivity can be, wrote that every location is limited and all knowledge is situated: only partial perspective allows for objective vision. Against an analysis of the gaze as a male prerogative, Haraway also rescued the centrality of vision - and one might add visuality - as embodied, to 'reclaim the sensory system that has been used to signify a leap out of the marked body and into a conquering gaze from nowhere. This is the gaze that mythically inscribes all the marked bodies, which makes the unmarked category claim the power to see and not be seen, to represent while escaping representation' (188). With what Haraway (1991) would call the prosthetic eye of my camera limiting my visual possibilities and translating my way of seeing, I likewise started out to reclaim a specific, partial, different and embodied vision to organise my research, writing, and later curatorship of the exhibition.

Central to my situatedness are the entangled categories of ethnicity, class and gender. Each produces its own set of overlapping representations. As Ghassan Hage (2003) reminds us, multiculturalism seems to have become a neutral middle class multiculturalism, the working class - warts and all — having been removed from the field and from representation. Gender, on the other hand, as an interpretative category of diaspora has now its own history both in academic and creative writing (Vanni, 2001; Pallotta Chiarolli, 1999; Fortier, 1999 and 2000; Scarparo and Wilson, 2004), and it has reappeared as a non-neutral position in the experience of research itself.

1 This account of the procession, as well as other sections, have been reworked from the Italiani di Sydney exhibition catalogue. 
At one level, I recognise some of the cultural practices I chose to research and exhibit even when they are grounded and reterritorialised in specific localities other than the ones I inhabited in Italy or in which I presently live in Australia. On another level, I do not relate to them. I am first generation. I 'came out', as many ItaloAustralians I met would say to refer to their journey to Australia, on my own long after the major waves of postwar migration had stopped arriving in Australia. Just like the camera-tool I carried in the procession, I had enough cultural capital and language instruments to enable me to read and interact and fall in love with the multiplicity of non-Italian Sydney from the start. I happily live in the Italian diaspora. I travel and I work with Italian colleagues and friends, maintaining my daily links with Italian realities enough to be immune from narratives of both pervasive nostalgia and the grandeur of civiltà italiana, which seem to animate institutional recollections of Italy.

What appear to be common experiences of both Italian first generation migrants and Italo-Australian second generations are alien to me, although the sense of diversity and dislocation, sometimes of loss, are not. This slippage has created a productive "mobile' positioning, one that takes into account "the impossibility of innocent "identity" politics and epistemologies as strategies for seeing from the standpoint of the subjugated in order to see well' (Haraway, 1991: 192).

These distinctions are important when one is put in a position to produce representations of the Italian diaspora because, as Ivan Karp acutely observed:

What is at stake in struggles over control of objects and the modes of exhibiting them, finally, is the articulation of identity. Exhibitions represent identity, either directly through assertion, or indirectly, through implication. When cultural 'others' are implicated, exhibitions tell us who we are and, most significantly, who we are not. Exhibitions are privileged arenas to present images of self and other. (15) 
In the specific case, this challenge was further complicated by traversing and mediating the poetics and politics of an AngloAustralian museum and of an imagined Non-English-Speaking Background (NESB) community. As a curator, but also as an academic, the challenge is to be at the same time self and other, 'a split and contradictory self' (Haraway,1991: 193), avoiding the pitfalls of self-orientalism of people who, like me, still work in area studies. A parallel tension actively prevented me from fetishising Italian cultures in Sydney as marginal, subaltern or simply oppositional, in what I would term an essentialisation of difference. Rey Chow (2002a: 175) expresses similar concerns:

In the increasingly globalized realm of theoretical discourse, a habitual move may be readily discerned in critical discussions regarding marginalized groups and non-Western cultures: the critic makes a gesture toward Western theory, but only in such a way as to advance the point that such theory is inadequate, negligent, and Eurocentric. As a consequence, what legitimates concern for the particular group, identity, or ethnic culture under discussion (which for the purposes of this essay I will simply call X) is its historical, cultural, gendered difference, which becomes, in terms of the theoretical strategies involved, the basis for the claim of opposition and resistance.

Reflecting on my own vision of the exhibition made me understand how a 'transparent' point of view, as if my gaze coincided with the desires of 'the Italian community', would have led to 'a serious danger of romanticizing and/or appropriating the vision of the less powerful while claiming to see from their positions' (Haraway, 1991: 191). Although the many individuals, organisations and institutions that eventually made up the exhibition are not less powerful than I am (in some cases quite the contrary), the specificity of curatorship handed me the authority over representation. This shift in the balance between me and some of the communities' gatekeepers was not harmless. Interestingly, in the struggle for the control of objects, 
gender became an issue. While I was conducting interviews, for instance, it was not uncommon for the interviewee to address replies to my questions to my project manager, a man of Anglo-Australian appearance.

This particular situatedeness led me to curate one type of exhibition over another and consequently to privilege a certain type of representation. Rather than simply describe and memorialise the exhibition however, I want to consider the theoretical concerns I encountered while producing it. Notions of imagined communities, the poetics of the carnivalesque, the everyday, quite simply the importance of objects, cultural heritage in the making, heterogeneity and heteroglossia, hybrid spaces, hyperlinked narratives, and the gaps between official narratives and lived actualities inform my reflection.

\section{Celebrate!}

Everybody spread the word

We're gonna have a celebration

All across the world

In every nation

It's time for the good times

Forget about the bad times, oh yeah

Madonna, Holiday 1982

When in March 2001, I was approached by the MoS to provide a concept for an exhibition on Italians and Sydney, the brief was broad: the only strong sentiment was a desire to engage with diversity in order to celebrate the multifarious Italian contributions to the city of Sydney. The exhibition was also to include a rich public program, aimed at both attracting audiences who would not normally visit the museum and at inviting museum goers to explore the social landscapes of Italian Sydney. I proposed a tongue-in-cheek exhibition entitled Sydney, Italia, to be read as an address implying both that the influence of Italian culture had been pervasive and, borrowing from Dipesh Chakrabarty (2000), signalling the need to 'provincialise' Italy. The HHT Director rejected this title, suggesting something 
'more Italian'. Thus the exhibition became Italiani di Sydney. It opened at the end of August 2003 and ran for three months during which time it was visited by more than 21,000 people, an outstanding number for the MoS. In the past I had loved the MoS because it was sophisticated in its engagement with cultural issues and did not reduce everything to chunks consumable by a twelve-year-old child. I liked the idea that an Anglo-Australian institution such as the MoS was finally opening up to non-Anglo Australians.

I soon realized that the HHT was a complex and opaque institution, a blend of the progressive, the conservative and the market-oriented. Here ethnicity was the issue that overwhelmingly came to the fore: by contracting me, an Italian, to curate an Italian show, the whole process of representation was hopefully to become more transparent and less problematic. This idea was shared also by many of the ItaloAustralian people who took part in the project: as far as they were concerned I was one of them; gender and class differences receded into the background. At the MoS I worked closely with an enthusiastic and creative exhibition team. I carefully put together a steering committee conceived as a horizontal network, with Italian organisations as gatekeepers, as well as individuals with very few connections to formal organisations. I also invited representatives of the Italian Government in Sydney, the Italian Consulate and Institute of Culture to be part of this network but both institutions decided not to contribute. We tried to follow an inclusive, even random, principle in the choice of stories and objects collected for the exhibition.

Very early in the process we wrote letters to every Italian organisation in Sydney some of which were open to questions and eager to collaborate. Some had their own agendas and definite ideas on how the show should be organised and what it should include and more importantly, who should be in charge of it and who should be excluded. Others did not want to be involved, showing the common uneasiness of Australians from a non-English-speaking background (NESB) people towards cultural institutions (Jakubowicz, 2000). This lack of engagement confirmed what I already knew: that in spite of the rhetoric of multiculturalism, Italians, like most NESB people, do 
not feel, and indeed are not, represented at a cultural level by predominantly Anglo-Australian institutions. Italo-Australian filmmaker Monica Pellizzari succinctly described being Italian in Australia: 'I grew up addicted to television and yet never saw anybody that looked like my immediate family on screen. In the rare moments they were represented, they were misrepresented' (Colbert 1997: 23).

I thought the MoS could make a difference in this rather bleak representational picture and organise an exhibition 'with' rather than 'on' individuals willing to share their stories. The MoS was also convinced that the exhibition had to be 'for' Italians and had to target that specific audience. Of course I did not set out to offer an allencompassing exhibition on what it means to be Italian in Sydney but rather to give glimpses of how some Italians imagined themselves as Italians. Moving Anderson's (1991) analysis of nations as imagined communities, metaphorically and literally, out of the 'nation', I wanted to explore how the translocal communities of the Italian diaspora were imagined communities and how they imagined themselves. This act of imagining begged the question of authority, that is, who imagines what, and why some of the imagined narratives found an endorsement and a public recognition and display while others did not. Italians of the diaspora structure themselves in countless regional, local, religious, business and welfare organisations to which one must add the representative bodies of the Italian State (the Consulate, Italian Institute of Culture, Italian Chamber of Commerce, Consiglio degli Italiani all'Estero, Comitato degli Italiani all'Estero, Comitato Assistenza Italiani). Depending on the economic and social capital of these organizations, some imagined narratives become official although that does not necessarily imply that they are shared. In my view it was clear, for instance, that the stubbornly highculture civiltà italiana envisaged by the Italian Government through the import of blockbuster exhibitions (e.g. Three Centuries of Italian Art, National Gallery of Australia 2002) or the sponsoring of classical music, had very particular class and cultural capital connotations and effectively cut off and alienated the majority of diaspora Italians. Having gone through the institutional channels of community organisations and their gatekeepers, I also started a more unorthodox 
kind of research: 'word of mouth, sit and have coffee and gossip' research. I interviewed more than seventy people who then contributed to the exhibition and I did a number of focus groups, traversing geographical, political, gender, class and age differences. I asked questions of belonging and resonance and I asked people to think of the objects or practices that they felt best represented them or to which they felt closest. I never mentioned the word 'Italian'. This process was both difficult and exhilarating at the same time.

The HHT deployed a politically neutral rhetoric to brand the exhibition, presenting it as a celebration of the contributions of the Italian community to the city of Sydney (HHT, 2003a and 2003b). The idea was catchy enough to be picked up by mainstream media and it figured in the opening night speech delivered by Carla Zampatti, Italo-Australian fashion designer and Chairperson of the multicultural media broadcaster SBS.,. Italian contributions, she explained, were always praised because Italians work hard, are not likely to cause problems in the workplace and integrate well. Although this last interpretation of 'celebration of the contributions' follows a distinct global capital logic, the idea of celebrating the Italian community's contribution to the city is actually much more opaque and it deserves to be clarified. Curled up into its folds, intricate power relations complicate the dynamics of representation. It has become a truism to state that communities are imagined; still, the use of the concept persists despite the fact that a community is solid, structured, manageable and easy to represent. Contributions also speak of an unbalance. The rhetoric of NESB contributions to Australian society implies that Italians cannot really be an integral part of the social, economical, cultural and political fabric of the city; they can only contribute to it. Similarly, it is easy to 'celebrate' diversity: it looks good, it feels good. Celebrating diversity endorses an image of gourmet multiculturalism: it is consumable, marketable and maintains the status quo. Cultural diversity has become the neutral in multicultural Australia, 'making', as the Australian Government declares, 'our nation one of the most harmonious societies in the world' (DIMIA:URL). As Hage argues, the focus on cultural diversity also marks 'a retreat of access and equity multiculturalism 
and the growing emphasis on identity multiculturalism' (2003: 110), finally adding to the de-politicisation of multiculturalism itself.

Celebrations do not alter social or political relations. I would argue, elaborating on Susan Smith after Bakhtin, that celebrations in a museum take the form of ritual ceremonies occupying 'a public space in order to state and reiterate the claims made by a dominant majority to a position of authority, to define history and traditions, to link the past with the present and to assert a vision of the future' (Smith, 1995: 143). Against these gestures of authority, Bakhtin juxtaposed the carnival. Both types of celebration reclaim public space as a symbolic deployment of social or political contests (Smith, 1995: 143). The ritual implies a spectacle and thus privileges passive consumption: it endorses a vertical relationship between who is in charge of the spectacle and who are spectators. It gives itself away at glance.

A carnival, on the other hand, calls for engagement, participation, experience through the body, a being-there and becoming-there that shape horizontal relations:

This festive organization of the crowd must be first of all concrete and sensual. Even the pressing throng, the physical contact of bodies acquires a certain meaning. The individual feels that he [sic] is an indissoluble part of the collectivity, a member of the people's mass body. In this whole the individual body ceases to a certain extent to be itself; it is possible, so to say, to exchange bodies, to be renewed (through change of costume and mask). At the same time the people become aware of their sensual, material bodily unity and community. (Bakhtin, 1984: 255)

Carnival is also associated with temporary subversion of everyday rules, the blurring of boundaries, and the turning upside down of social mores: 
[...] the suspension of all hierarchic differences, of all ranks and status; carnivalesque revelry is marked by absolute familiarity. Differences between superiors and inferiors disappear for a short time, and all draw close to each other... In the atmosphere of carnivalesque freedom and familiarity, impropriety also has its space.

(Bakhtin: 246-247)

To question the rhetoric of celebration that marked the show from the beginning, I wanted to translate the idea of the carnival into a museum practice. This called for a particular kind of installation, one that could be 'experienced' rather than simply looked at and one that would draw on familiarity, on non-hierarchical order, that would blur the boundaries of mainstream representations. Other borders needed to be blurred, such as those of the museum itself, by bringing into the institution 'improper' objects, objects that lived outside a museum designated to exhibit the history of the city. These borders, for all the museum project's intrinsic ability to swallow and incorporate dissonant voices, proved much more difficult to blur but eventually the Vespa scooter which was included in the show - I thought somewhat boldly - was as much at home in the exhibition space as the nineteenth century prints of colonial Sydney for which the MoS is famous.

\section{Everyday}

Many people chose objects of domestic use in their houses and gardens to represent their sense of often multiple belonging. A number of texts in social sciences and cultural studies have indicated a renewed interest in the themes of the everyday, and objects (Appadurai, 1996; Colebrook, 2002; Chow, 2002b), as well as practices of belonging - in relation to diasporic communities (Armstrong 1999; Pattie 1998). Anne-Marie Fortier (1999 and 2000) in particular - have woven together the categories of gender and ethnicity to re-focus on notions of place and belonging, in contrast to the attention paid to movement and travel by current transnational 
theories. Ian Chambers (1998) raised the question of what kind of a home migrants make when they have left home, arguing:

The question emerges not in the space of the conjunction, not in the 'and' that lies between home and hybridity, between domesticity and exile, between the stranger and the resident, but in the apprenticeship of learning to dwell in home as hybridity. Here there no longer lies the choice between the domestic and the exilic, but rather the prospect of occupying an ulterior space (Bhabha's 'third space'), in which both the familiar and the foreign are conjoined and mutually interrogated in a diverse 'wordling of the world' (Heidegger). Here, listening to what our identity says about us, and what it occludes, we perhaps become more hesitant in pronouncing where home concludes and the foreign commences. (39)

We commissioned a photographer, Vince Lovecchio, to take photos of four houses, two in the western suburbs and two in the eastern suburbs, with the aim of comparing them so as to suggest the variety to be found among Italians in Sydney. The objects selected by many contributors to Italiani di Sydney inhabited the hybrid space referred to by Chambers, being at once home and not home, cut off from their original terrain of belonging and re-territorialised in new personal, cultural, and social relations. In this passage, they acquired extra layers of meaning, or to borrow from Ernesto De Martino (1964), 'a semantic excess'.

Italian psychoanalyst Claudio Neri, reading Ernesto De Martino's essay 'Apocalissi Culturali e Apocalissi Psicopatologiche' (1964), interpreted migration as a crisi della presenza, or a crisis of presence (1998). This definition is used to indicate 'la perdita della propria collocazione in un momento storico. La crisi del cordoglio, la crisi del lutto, si collega a ciò: essa rappresenta la possibilità che i viventi vengano sopraffatti dalla perdita che hanno subito e non riescano a guarirne' (1998) ('...the loss of one's place in the historical moment. 
The crisis of mourning is linked to this and it represents the possibility that people can be overwhelmed by their loss and might not be able to heal.'). Neri associated this crisis with cultural apocalypses, those 'manifestazioni di vita culturale che coinvolgono, nell'ambito di una determinate cultura e di un particolare condizionamento storico, il tema della fine del mondo attuale, qualche che sia poi il modo col quale tale fine viene concretamente vissuta e rappresentata' (De Martino, 1964: 105) ('cultural manifestations involving, within one specific culture and historical moment, the theme of the end of the present-day world, regardless of the way this end is actually lived or represented'). Cultural apocalypses, however, also offer the possibility of redeeming loss through the deployment and socialisation of symbolic and everyday rituals which mark the beginning of renewal (Neri). Both Neri and De Martino centred their analysis on domestic or domesticated objects with De Martino in particular describing the beginning of a crisis of presence as the moment when objects become separated from 'la rete di relazioni domestiche, dalle memorie culturali latenti' (the web of domestic relation, from latent cultural memories) (122). In this separation, relations between people and objects become chaotic and objects themselves lose what De Martino terms appaesamento (130). This word is particularly relevant when placed in the context of migration, where objects - literally and figuratively - are separated from their usual net of domestic relations. Appaesamento embodies the sense of belonging to a particular place, to a paese (village, country). Its antithesis, spaesamento, describes the loss of one's bearings in the world, being outside known relations and places. Paese is also the fundamental unit that defines identity and belonging, pre-dating the idea of nation (Gabbaccia, 2000: 15). According to De Martino, once objects lose their appaesamento they undergo either a semantic loss or they can be charged with semantic excess (130-131). Many of the first generation objects in the exhibitions belonged to this type and were central to the continuous process of re-territorialisation and re-appropriation, or I would say, $r i-$ appaesamento, of the diaspora. On the other hand, other objects were new and disposable; commodities whose consumption ensured an almost immediate branding as Italian. 
All objects had different economic and symbolic values, different resonances. A series of 1988 black and white photographs of the community project Mondi Diversi organized by FILEF (the Federation of Italian Migrant Workers and Families) depicted Italian migrant workers. As a counter-narrative to 1950s representations of a world of happy, thriving, self-employed greengrocers, restaurateurs, tailors, concrete subcontractors and barbers, Mondi Diversi served as a reminder that over $70 \%$ of first generation Italo-Australians were employees working in unskilled or semiskilled jobs. Like other migrant workers from non-English-speaking backgrounds, they were generally concentrated in industries with higher than average accident rates and greater health risks. The immobility of the labour market, the risks inherent in the work, the racism and antagonism on the job were significant drivers for Italians to seek self-employment opportunities (Vanni, 2003: 7). Many often worked two jobs and overtime as they strove to achieve economic security. Women, far from the image of the Mamma-housewife, worked in the manufacturing industry: an original 1960s blouse was testimony to this.

The realm of food was also represented by several objects - cutlery, spoons, plates and ricette In a documentary by Robert Pittorino, Smells Good Grandma, his family discussed 'being Italian' through the preparation and consumption of a traditional Sunday lunch, Sicilian style. Michael Schiavello's video All'arenga depicted a particular, traditional way of eating polenta belonging to peasant cuisine (Vanni, 2003: 7). This work was also a comment on multiculturalism as, to recreate the dish, his parents had first to source implements and ingredients in Asian food stores. A series of pop paintings of Italian food packages by Steve Fasan provided a witty comment on the iconic status of Italian food in Sydney, while the place of coffee in the making of italianità was ironically interrogated by artist Thomas Scirè. Objects of devotion, images of saints, statuettes of the Madonna, were part of everyday life and aesthetics (Vanni, 2003:7). Deborah Scirè commented on the pervasive presence of religiosity in a series of paintings depicting guardian angels. Religion and religiosity and the weight of religion in the way people socialise - defining and making visible their identity through 
affiliations to particular saints or festivals - were explored through photos and the Brotherhood of San Bartolo's sash.

While the cult of a particular saint reflected the sense of belonging to a particular paese, the role of soccer in bringing Italians together beyond localism was explored in the film Leichhardt 2002 World Cup by Paul Jones, Peter Oldman, Mark Sanfilippo and Ilaria Vanni, which was shot in the Italian neighbourhood during the 2002 Soccer World Cup (Vanni, 2003:7). Sport has also a precise influence on style. A group of young second-generation Italians used soccer accoutrements to mark out their identity (Vanni, 2003:7). The possibility of new forms of postmodern identity, acquired through consumption of certain items, was explored in the notion of everyday objects that had become 'successful because they incorporate the depiction of the icon of Italy, that is, they contain an emotional quality, they are signs of a desire produced by the image of Italy, which is present in the minds of one and all' (Malossi, 1999: 29). 'Italian style', fashion and clothes partake of this iconic status. A young artist, Elvis Di Fazio, played with this sense of iconicity in a series of paintings of Sophia Loren quoting Andy Warhol's Marilyn Monroes. The exhibition also included an early official narrative on the benefits of consuming Italy - the Italian Government promotion of Italian products at David Jones store in 1955 and 1966. As a counter-narrative we included contributions from contemporary Italo-Australian designers, reinterpreting and thus producing Italian cultural heritage. Clothes belonging to individual lenders also introduced the idea of a connection between memory and body while reminding the viewer that many Italian migrant women worked in the clothing industry.

A 3D designer rebuilt a market stall and a bar, with a working soccertable (like those found in Italian bars) as the centerpiece of the show. Kids and adults alike played soccer while the film on la Nazionale's supporters during the 2002 Soccer World Cup played in the bar area. People could sit on a designer bench at a long display cabinet in the form of a glass-topped table which contained objects of domestic usage relating to the kitchen: hand-made wooden spoons, a set of $19^{\text {th }}$ century silverware, antique majolica plates and brand new Versace 
Medusa collection dishes, doilies, moulds. From the bench they could also watch a selection of short films. Around the MoS gallery there were also clothes, shoes, saint cards, a giant crocodile made of bread, puppets, soccer paraphernalia, passports, old and new photos, jewellery, contemporary art, ocean liner tickets and postcards of the ships that brought people to Sydney between the end of the Second World War and the 1960s. Also on display were exquisite embossed aluminum works by artist Rox De Luca on the themes of the journey out and racism, hand-made brooms, a scrapbook, biscuits, coffee cups and coffee, glamorous photos of models wearing Pucci prints from the exhibition of Italian mechandise sponsored by the Italian Government at David Jones in 1966, including a multimedia presentation of images on its centerpiece, a plaster of Paris copy of Michelangelo's statue of David and a fragment of the statue itself, a finger rescued in Melbourne through a highly successful breakfast radio program which was broadcast on $\mathrm{ABC}$ nationally.

Heteroglossia and Webbed Accounts (Haraway, 194)

Italiani di Sydney was intended to reflect on the contemporary reality of Italian culture in Sydney as a heterogeneous and fluid entity. This emphasis on heterogeneity arose from the observation that mainstream narratives on Italian migrant cultures tend to isolate the experience of migration in time and space, in an ethnographic present where they become migrated cultures. These narratives operate within that evocative and wistful archetype that James Clifford has described: 'The salvage paradigm, reflecting a desire to rescue "authenticity" out of destructive historical change is alive and well. It is found not only in ethnographic writing, but also in the connoisseurship and collections of the art world and in a range of familiar nostalgias' (Clifford, 1987: 121). In following this stereotype, such narratives tend to isolate migrant experiences from the social and political fabric of Australia, borrowing alternatively from the rhetoric of the epic, with tales of hardship and settlement and the multicultural picturesque, concentrating on the aesthetics of food, religion and, more recently, sport and style. 
These mainstream narratives, it is important to stress, are the result both of self-representation and of non-Italian, mainly Anglo Australian representations. While the non-Italian use of stereotypes of italianità oscillates between orientalism, marketing and the Stendhal syndrome, it was its use in self-representation that was brought to the fore in the exhibition. Stereotypes are often embraced and sometimes cultivated as ethnic identity statements: ethnicity finds its authorisation in the repetition of the stereotype. In this sense, the stereotype sets the boundaries within which ethnicity can be performed. At the same time, the very act of reiteration lends reality to the stereotype. Some Italians do eat pasta, they do make tomato sauce in big cauldrons in the back 'yarda' with their extended families and do go on processions following the statue of a saint. Some Italians do listen to old-fashioned melodic Italian music and some to more recent Italian pop. They watch soccer and drink lots of coffee but this could also be said about many Australians. They do so because these actions are acknowledged to be part of their cultural heritage. While in some cases this can be seen as an act of resistance against assimilation into mainstream culture, in other cases, for instance in the hyper-real italianità of second and third generations, the stereotypes are reappropriated with irony. In other cases again, stereotypes and mainstream representations simply do not apply (Vanni, 2003:3-4). These differences were explored in the exhibition: 'Rather than refusing these representations, Italiani di Sydney accepts the discrepancies between official, unifying narratives and the multitude of localised lived experiences. These contradictions are based on notions of a homogeneous italianità articulated in an imagined community with a shared set of invented traditions, and a living actuality where differences and exchanges have long been the norm' (Vanni, 2003: 4).

As a curatorial strategy for Italiani di Sydney I opted for messiness. Messiness, in my view, reflected both the nature of the content and the process that led to the exhibition. There is nothing crystal-clear and tidy in projects involving living cultures: messiness is natural to them. 'It conveys the state of flux, fragmentation and turbulence, the constant, everyday re-making of cultural heritage. The objects 
presented were eclectic, from archival material - mainly old photographs - to objects of common use, to multimedia presentations. Several works by young and emerging artists engaged with the poetics of the exhibition, providing a reflective and often ironic commentary' (Vanni, 2003: 6). To engage with messiness, fragmentation and contrasts, I tried to withdraw from the 'struggles over control of objects and the modes of exhibiting them' (Karp, 1991: 15). Rather than trying to find a mythical common language for Italiani di Sydney, I opted for heteroglossia - the Museum voice, the curatorial voice, dissonant individual voices and the voice of the imagined community. We - I, the curator, the MoS, my steering committee, the persons I interviewed - chose objects that resonated, objects that:

can reach beyond their formal boundaries to a larger world, to evoke in the viewer the complex, dynamic cultural forces from which it has emerged and from which it might be taken by a viewer to stand ... that invite a reflection on the unstable circumstances of their production and consumption, and then solicit the viewer to take a leap and analyze how these circumstances relate to our own. (Greenblatt, 1991: 42)

The objects, although doubly 'charged with semantic excess' (De Martino, 1964: 130-131) - the first time by their re-territorialisation into the 'home as hybridity' (Chambers, 1998: 39), the second by the further passage into the museum gallery - told only fragments of tales. In the exhibition, they were presented as 'webbed accounts' (Haraway: 194) rather than in a linear story. The plurality of webbed and resonating accounts was aimed at reflecting the heterogeneity of italianità. While visiting the exhibition from the perspective of one account, it was possible to follow this resonance and jump into another narrative. These hyperlinks might have been the story of one person told across different narratives or objects emerging in several stories. There was no beginning or end. Although the narratives traversed a time span from the late 19th century to the present, the exhibition itself did not follow a precise chronological order. The accounts were also interactive: they were expected to be completed by 
the visitors, to encourage them to fill in their own experiences and thus make up their own Italian story (Vanni, 2003: 9).

(University of Technology Sydney)

\section{References}

Anderson, B.

Appadurai A. (ed)

Armstrong, W.

Bakhtin, M.

Chakrabarty, D.

Chambers, I.

Chow, R
1991 Imagined Communities, London and New York: Verso (1983).

1996 The Social Life of Things. Commodities in Cultural Perspective, Cambridge: Cambridge University Press.

1998 Belonging, ethnic diversity and everyday experience: co-existing identities on the Italo-Slovene frontier WPTC-98-05, Transnational Communities Programme Working Paper Series. URL accessed 12-02-2005

http://www.transcomm.ox.ac.uk/ working\%2papers/Armstrong.PDF

1984 Rabelais and his World, Bloomington: Indiana University Press (1965).

2000 Provincializing Europe. Postcolonial thought and Historical Difference, Princeton and Oxford: Princeton University Press.

1998 A Stranger in the House. Communal/ Plural, 6 (1): 33-49

2002a Sentimental Returns: On the Use of the 
Everyday in the Recent Films of Zhang Yimou and Wong Kar-way. New Literary History, 33: 639-654

Chow, R.

Clifford, J.

Colbert, M.

Colebrook, C.

De Martino E.

DIMIA

Fortier, A. 2002b The Interruption of referentiality: Poststructuralism and the Conundrum of Critical Multiculturalism. South Atlantic Quarterly, 101 (1): 175-190

1987 Of other peoples: Beyond the salvage paradigm", in Discussions in Contemporary Culture, Foster H. (ed), DIA Art Foundation, No 1, Seattle: Bay Press: 121-9.

1997 Bi-cultural vision: The Films of Monica Pellizzari. Cinema Papers, 117: 22-25.

2002 The Politics and Potential of Everyday Life. New Literary History, 33: 687706.

1964 Apocalissi culturali e apocalissi psicopatologiche. Nuovi Argomenti, 69-71: 105-141.

Department of Immigration and Multicultural and Indigenous Affairs: http://www.immi.gov.au/multicultural/diversity/ community.htm

1999 Re-membering Place and the Performance of Belonging(s). Theory, Culture \& Society, 16 (2): 41-64.

2000 Migrant Belongings. Memory, Space 
and Identity, Oxford and New York: Berg.

Gabbaccia, D. 2000 Italy's Many Diasporas, London: UCL Press.

Greenblatt, S.I. 1991 Resonance and Wonder, in Karp \& Lavine S.D. (eds) Exhibiting cultures. The poetics and politics of museum display, Washington and London: Smithsonian Institutions Press: 42-56.

Hage, G.

2003 The Class Aesthetics of Global Multiculturalism, in Against Paranoid Nationalism. Searching for Hope in a Shrinking Society, Annandale: Pluto Press: 108-109.

Haraway, D.

1990 Situated Knowledges: The Science Question in Feminism and the Privilege of Partial Perspective, in Simians, Cyborgs and Women: The Reinvention of Nature, New York: Routledge 1991: 183-201.

Historic Houses Trust 2003a Italiani di Sydney, in Insites, of New South Wales, Spring 2003: 8

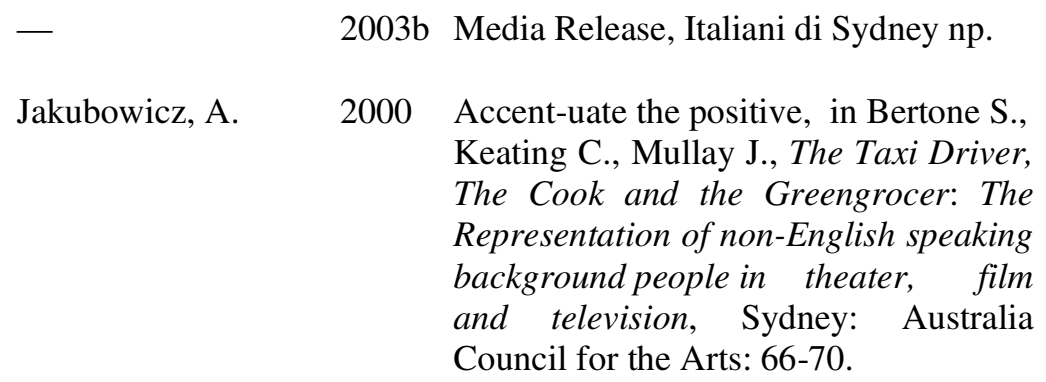


Karp I.

Malossi G.

Neri, C.
1991 'Culture and Representation', in Karp I. \& Lavine S.D. (eds), Exhibiting cultures. The poetics and politics of museum display, Washington and London: Smithsonian Institutions Press: $11-24$

1999 Volare, the icon of Italy in global pop culture, in Malossi G. (ed) Volare, the icon of Italy in global pop culture, New York: Monacelli Press: 24-29.

1998 Il calore segreto degli oggetti: a proposito di un saggio di Ernesto De Martino, paper delivered to the conference Apocalissi alle soglie del duemila, Roma, 2-3 October 1998, Museo Nazionale delle Arti e Tradizioni Popolari, n.p.

Pallotta Chiarolli, M. 1999 Tapestry, Milsons Point: Random House.

Pattie, S.

1999 Longing and belonging: issues of homeland in the Armenian diaspora WPTC 99-11: "http://www.transcomm. ox.ac.uk/working\%20papers/pattie.pdf" Accessed 120205

Scarparo, S. \& Wilson, R.

2004 Across genres, gerations and borders: Italian women writing lives, Newark: University of Delaware Press.

Smith, S.

1995 Where to Draw the Line: A Geography of Popular Festivity, in Rogers A. and Vertovec S. (eds), The Urban Context, 
Ethnicity, Social Networks and Situational Analysis, Oxford and Washington: Berg Publishers: 141-164.

Vanni, I.

2001 Cross-stitching objects, memory and cultural difference, in Treppa $\mathrm{H}$ and Vanni I. (eds), Stitches-Fare il punto, Sydney: Australian National Maritime Museum: 6-13.

2003 Italiani di Sydney, exhibition catalogue, Sydney: Historic Houses Trust of New South Wales. "http.//www.hht.nsw. gov.au/museums/museum_of_sydney/ museum_of_sydney". 